\title{
CHEMICAL AND PHISICAL ASPECTS OF HOP-PLANT DRUG AND IT'S ACTIVITY TO ACNE VULGARIS AGENTS
}

\section{ХІМІКО-ФІЗИЧНІ АСПЕКТИ ПРЕПАРАТУ ХМЕЛЮ ТА ЙОГО ДІЯ У ЛІКАХ ВІД АКНЕ}

\author{
Torianyk Inna ${ }^{1}$ \\ Moiseienko Tetiana ${ }^{2}$ \\ Kazmirchuk Viktor ${ }^{3}$
}

DOI: https://doi.org/10.30525/978-9934-571-78-7_48

Abstract. The authors of work present updated on the problem of modern medicinal liniment drags using in complex therapy of acne vulgaris infection, types of this preparations, prescription quotient on doctor's of a medicine, criteria of effectiveness and prognostic factors. This article includes data about the activity of a new hop-plant medicine (have been synthesized in an antimicrobial laboratory of State Institution «Institute of Microbiology and Immunology of National Academy of Medical Sciences of Ukraine») to bacterial agents of acne vulgaris, fungistasis influence. This publication contains information on modern diagnostic and treatment concepts of acne vulgaris infection, specific genesis of the patients who had a different class of damages (acne congiobata, (L70,1), acne necrotlca, (L70,2), acne tropicalis, (L70,3), childhood acne, (L70,4), acne excoree, $(\mathrm{L} 70,5))$ and general injuring from gastro-intestinal tract's, endocrine, reproductive system, common aspects of classification and typology this nosology. Authors focuses attention on generalized nature of process development, on gross damage of the main structural and functional units of acne vulgaris infection, chemical and phisical aspects of a new hopplant drugs. The purpose of the planned study chemical and phisical aspects

${ }^{1} \mathrm{PhD}$, Leader Research Scientists at Laboratory of Viral Infection,

State Institution «I. Mechnikov Institute of Microbiology

and Immunology National Academy of Medical Sciences of Ukraine», Ukraine

${ }^{2}$ Postgraduate Student at Laboratory of Antimicrobial Agent's,

State Institution «I. Mechnikov Institute of Microbiology

and Immunology National Academy of Medical Sciences of Ukraine», Ukraine

${ }^{3} \mathrm{PhD}$, Head of Laboratory Antimicrobial, Laboratory of Antimicrobial Agent's,

State Institution «I. Mechnikov Institute of Microbiology

and Immunology National Academy of Medical Sciences of Ukraine», Ukraine 
of drags using on treatment of acne vulgaris infection, detected level of influence microorganisms on its clinical course, stages and characteristic. The scientific novelty of the obtained results consists in the use of the received drug for the increasing effectiveness of the complicate acne vulgaris infection forms therapy. The research methodology was based on a algorithm of a complex of clinical, microbiological, biochemical, biophysical methods. It was established, that staphylococcal dominance was determined in two thirds $(79.6 \%)$ of patients with prevalence of S. aureus $(48.9 \%)$ on this pathology. In this publication also contains information on characterization of gel composition with extract of carbon dioxide hops-plant according to the leading physicochemical properties. The authors have studied in detail the rheological indicators (plasticity, elasticity, structural viscosity, thixotropy) of a new drugs. In the results of laboratory analysis was esteblished, that the shear stress and structural viscosity of the developed gel were determined, reaching 38.74-193.05 $\mathrm{Pa}$ and $38.74-0.44 \mathrm{~Pa}$. As a result of the study an antimicrobial activity (Staphylococcus epidermidis, S. aureus, S. Saprophyticus; Pityrosporum :P. Ovale, Orbiculare) of this application was proved.

\section{1. Вступ}

Акне (вугрова хвороба) - це хронічне мультифакторіальне захворювання апарату сальних залоз, що маніфестує переважно в пубертатному віці і характеризується гіперпродукцією шкірного сала, порушенням процесів фолікулярної кератинізації, колонізацією Propionibacterium acnes та запаленням [1, p. 479-480; 10, p. 7-9].

Акне посідає провідне місце за поширенням серед захворювань шкіри і з'являється у дітей після початку продукції андрогенів наднирковими і статевими залозами, і зазвичай стихає після закінчення росту. Проте вона може продовжувати проявлятися серед значної частини дорослих людей, особливо у жінок. Навіть після одужання залишаються такі негативні наслідки, як шрами та пігментні плями. Частота вугрової хвороби у підлітків від 80-90\% і більше, а у віці старше за 25 років - близько $11 \%$. У деяких жінок акне з'являються у віці 20-30 років. Перевага ступеня тяжкості у чоловіків в порівнянні 3 жінками з віком зростає [12, р. 474-476; 14, р. 5-9; 13-21].

Відповідно до Міжнародної Класифікації Хвороб десятого перегляду (MKX-10), група акне (L70) відноситься до патології придатків 
шкіри; до неї входять декілька підгруп: acne vulgaris (вугрі звичайні, L70,0), вугрі коглобатні (acne congiobata, L70,1), вугрі віспоподібні (acne necrotlca, L70,2), вугрі тропічні (acne tropicalis, L70,3), дитячі вугрі (childhood acne, L70,4), екскорійовані вугрі (acne excoree, L70,5), інші вугрі (L70,8), вугрі неуточнені (L70,9) [12, p. 474-84; 14, p. 3-34].

Розповсюдженість хвороби сягає 90\% в період пубертатну та зменшується до $80 \%$ у віковій групі $18-25$ років, серед дорослих віком 25-35 років зустрічається в 8\%, дедалі зменшується до $3 \%$. Але прогрес сучасної фармакологічної та нетрадиційної медицини не в змозі загальмувати ріст захворюваності на вугрову хворобу. Рандомізовані дослідження свідчать, що останніми десятиріччями середній вік акне збільшився з 26 до 40 років, а захворюваність в популяції 25-40 років на сьогодні складає 40-54\%. Частота тяжких форм збільшилась з 5\% до 14\% в спектрі загальної захворюваності на вугрову хворобу [12, p. 474-485].

В Україні статистичного обліку за цими категоріями не здійснюється. Акне входить до великої категорії інфекцій шкіри та підшкірної клітковини, захворюваність на які в 2009 році становила 1389,7 на 100000 населення. На думку експертів, акне та акнеформні дерматози посідають одне з перших місць в структурі всіх уражень шкіри та підшкірної клітковини. Причини етіопатогенезу акне на сьогоднішній день вивчено недостатньо. Зазначено в МКХ-10, що в розвитку захворювання мають важливе значення такі фактори: 1) збільшення продукції шкірного сала; 2) надмірний фолікулярний гіперкератоз; 3) вплив мікрофлори (Propionibacterium acnes); 4) розвиток запалення. Нещодавно стало відомо, що дегідротестостерон має найбільш виражений стимулюючий ефект в присутності пероксидів ліпідів. У шкірному салі хворих, які страждають на акне, зазвичай виявляється підвищена кількість пероксидів ліпідів, в той час як вміст основного антиоксиданту шкіри, вітаміну Е, навпаки, знижений. Пероксиди ліпідів також можуть впливати на процес дозрівання кератиноцитів сальної залози, порушуючи їх нормальне відлущування [15, p. 39-41].

Акне може бути спровоковане різкою зміною гормонального статусу. Наприклад, акне під час вагітності, після аборту, або в період менструації. В особливу групу виділяють так звані пізні вугрі (асnе climacterica), пов'язані з відносною гіперандрогенією в період менопаузи. Крім того акне, можуть бути у пацієнтів з синдромом Кушинга, внаслідок посилення продукції андрогенів. 


\section{Chapter «Medical sciences»}

На шкірі людини знаходиться велика кількість мікроорганізмів різних таксономічних груп. Останній факт був доведений не лише традиційними методами, але й новими перспективними засобами діагностики [8, p. 968-970]. Акне не відноситься до інфекційних захворювань, але роль мікроорганізмів у патогенезі доведена. При послабленні захисних механізмів організму мікроби проникають у сально-волосяной фолікул (СВФ), що обумовлює запальні явища і пустулізацію. На шкірі, схильній до враження акне, вирізняють різні групи мікроорганізмів - P. acnes, Staphylococcus epidermidis, S. aureus, S. saprophyticus, стрептококи, ліпофільні дріжджі роду Malassezia раніше відомі, як Pityrosporum (P. ovale та orbiculare). Стафілококи, пропіонобактерії та гриби роду Malassezia є мікроорганізмами, що складають до 99\% мікрофлори здорової шкіри [11, p. 173-180].

Гриби роду Malassezia живуть на шкірі людини і теплокровних тварин та володіють унікальними властивостями. Унікальність полягає в тому, що вони являють собою яскравий приклад здатності грибів, в залежності від умов навколишнього середовища та імунітету господаря, проявляти властивості коменсала, або патогенна. Провідні науковці вважають, що не менше 90\% населення є носіями Malassezia spp. Гриби знаходяться в межах верхньої частини протоки СВФ між поверхневими пластинками кератину. На шкірі людини найбільша щільність колонізації відзначається в багатих сальними залозами ділянках, а саме, в області волосяної частини шкіри голови, комірцевої зони, на обличчі, а також в області геніталій. Крім того, це єдиний представник мікрофлори людини, для життєдіяльності якого необхідні жири. Жоден з інших видів грибів не володіє властивостями облігатної ліпофільності [6, p. 61-81; 12, p. 474-480].

При акне у розвитку запалення важливу роль відіграють не-спороутворюючі грампозитивні анаеробні бактерії $P$. acnes, як один 3 провідних інфекційних агентів. Причиною для розмноження цих мікроорганізмів усередині СВФ, може бути закупорка устя волосяного фолікула і скупчення всередині шкірного сала. Мікроаерофільні бактерії P. acnes добре ростуть у таких умовах. У зв'язку з цим, чисельність $P$. acnes у комедонах, особливо закритих, у багато разів перевищує вміст аеробних бактерій (коки). P. acnes беруть участь в утворенні комедонів, а також у перетворенні їх на запальні морфологічні елементи акне [10, р. 7-9]. 
Мікроорганізми завжди присутні в комедонах, вони постійно знаходяться на поверхні здорової шкіри обличчя і $є$ складовою нормальної мікрофлори. Коки знаходяться переважно у верхній частині волосяних фолікулів або в місцях відкритих протоків потових залоз і не відіграють значної ролі в патогенезі акне. Мікробне оточення у воронці волосяного фолікула включає P. acnes та P. ovale. Вищезазначені збудники продукують ліпазу, активують комплімент, підсилюють десквамацію гирла волосяного фолікула і це призводить до його закупорки. Мікробні ліпази розщеплюють ди- та тригліцериди, утворюють вільні жирні кислоти, які становлять приблизно 20\% ліпідів поверхні шкіри у пацієнтів з акне. Комедоноген регулює хемотаксис, цей процес змінює кератинізацію, привертає нейтрофіли до фолікула, викликає утворення пустул та папул. Пошкодження стінки фолікула, накопиченням вільних жирних кислот і збільшенням внутрішньо-фолікулярного тиску внаслідок запалення призводить до розриву фолікулів, утворення вузлів, абсцесів та рубців [10, p. 7-9].

У межах середньої частини воронки волосяного фолікула локалізуються S. epidermidis та інші мікрококи. При вивченні шкіри хворих на акне виявлено домінування спільноти стафілококів, які виділено у двох третин (79,6\%) пацієнтів, і звертає на себе увагу превалювання штамів $S$. aureus $(48,9 \%)$ при даній патології. Можливо, це пов'язано 3 наявністю мікропошкоджень шкіри (екскоріацій) в області висипань, що і обумовлює більш високу частоту виявлення $S$. aureus. Найглибше в фолікулі виявляють мікроанаеробні пропіонобактерії. Серед них виділяють три типи: P. acnes (тип 1), P. granulosum (тип 2) та P. parvum (тип 3) [15, p. 39-41].

Більшість науковців вважають $P$. acnes основним видом бактерій, які зумовлюють розвиток акне, оскільки вони не володіють вираженими вірулентними властивостями і не проникають у шкіру, а знаходяться у вивідній протоці сальної залози. Запальні явища в останній, так само як і утворення комедонів, пов язані з метаболітами бактерій. При бактеріологічних дослідженнях мікрофлори комедонів у $17 \%$ випадків виділені та ідентифіковані P. granulosum, у 67\% - P. acnes. Інші автори, що описують вміст мікроорганізмів при ВX, визначають наявність $S$. aureus, біохімічно неактивні грампозитивні палички і мікрококи (P. granulosum, S. aureus та $S$. viridas). У некротичних вуграх виявлені $S$. aureus з високою вірулентністю. Стафілококи ста- 


\section{Chapter «Medical sciences»}

новлять 57-83\% від загальної кількості монокультур, які виявляють на шкірі і нерідко асоціюються з грампозитивними паличками. Їх активація може сприяти окремі фракції ліпідів. На шкірі здорових людей, в основному знаходяться непатогенні $S$. epidermidis, S. saprophyticus, $S$. aureus та стрептококи. Симбіоз анаеробного P. acnes і аеробного $S$. aureus при перевазі першого виду бактерій вважають однією з безпосередніх причин розвитку ВХ. Проте, наявність $P$. acnes, як в елементах вугрового висипу, так і на здоровій шкірі, спонукає до сумнівності цієї точки зору. Бактеріологічними дослідженнями при акне виявлено, що асоціації мікробів зустрічаються в 1,7 раза частіше за монокультури: $17 \%$ становлять монокультури $S$. aureus, $20 \%-S$. piogenes, $33 \%$ - acoціація $S$. epidermidis з $S$. enaerobius, $18 \%-S$. epidermidis з $S$. viridas, $12 \%$ - грампозитивні S. saprophyticus і грамнегативні Escherichia coli. У комедонах, крім P. acnes і стафілококів, виділяють дріжджоподібні гриби (Malassezia), які також мають патогенетичне значення. Вважають, що P. ovale та P. acnes, які у здорових осіб поводять себе як сапрофіти, при ослабленні захисних властивостей шкіри можуть викликати iї ураження. На тепер існують численні публікації щодо унеможливлення розвитку акне за рахунок посилення захисного потенціалу кишківника шляхом застосування пробіотиків, лактобактерій, біостатиків, поширюються погляди на новітні методи лікування та профілактики mesh-інфекцій [3, p. 136-141; 4, p. 11-17; 5, p. 563-567; 7, p. 7-13].

В етіопатогенезі акне приймають участь й інші мікроорганізми, зокрема стафілококи та гриби роду Candida. Це пояснюється тим, що відповідні мікроорганізми не виживають в протоках сальних залоз без доступу кисню. При ураженнях шкіри з обтяженим перебігом акне встановлено збільшення питомої ваги монокультур $P$. acnes та $S$. aureus на тлі зменшення сапрофітів, зокрема S. epidermitis. Крім цього, виявлено збільшення частки бактерій, резистентних до антибіотиків, що корелюється зі ступенем тяжкості дерматозу. Запальна реакція та імунна відповідь у дермі обумовлена $P$. acnes, внаслідок ушкодження епітелію ліпазою, протеолітичними ферментами, ензімами. На ранньому етапі виникає міграція лімфоцитів у вогнище запалення, що призводить до лімфоцитарного типу запалення епідермісу. Активація компліменту - наступний етап запалення, медіатором цього процесу $\epsilon$ сама клітинна стінка $P$. acnes. Нейтрофіли, виділяючи літичні ензими, збільшують пошкодження епітелію фолікулів. У вигляді про- 
вокуючих факторів запальної реакції можуть виступати певні цитокіни. Вивільнення інтерлейкіна- $1 \alpha$ викликає морфологічні зміни, які відбуваються під час формування комедонів. Таким чином, запалення може виникати на будь-якій стадії вугрової хвороби, при цьому воно може бути поверхневим і глибоким, що і обумовлює клінічні прояви, які великою мірою зумовлюють у подальшому якість життя пацієнтів [9, Н. 947-950]. Отже, всебічне вивчення широкого якісного спектру нових препаратів рослинного походження (у тому числі, на основі екстрактів хмелю) видається своєчасним.

\section{2. Характеристика гелевої композиції з екстракту хмелю}

\section{вуглекислотного за провідними фізико-хімічними властивостями}

Визначення $\mathrm{pH}$ середовища гелю з екстрактом хмелю вуглекислотного (ЕХВ) 1\% проводили за методом потенціометрії. Показники $\mathrm{pH}$ середовища гелю, в яких активна речовина стабільна, проявляє найбільшу протимікробну активність, не викликає подразнення, а лікарська форма має оптимальну консистенцію, знаходяться в діапазоні 5,0-7,0 [7, p. 7-9]. Однорідність гелю на основі екстракту хмелю вуглекислотного 1\% вивчали за методикою однорідності відповідно ДФУ 2 (державної фармакопеї України 2). За визначенням однорідності гелю встановлено, що у разі огляду неозброєним оком у всіх пробірках відсутні видимі частки і відсутні сторонні включення. Дані дослідження довели, що розроблений гель відповідав вимогам тесту випробування, був однорідним.

Гелі, що відносяться до м'яких лікарських засобів - це структуровані системи з пластично-пружно в'язким дисперсійним середовищем. Гелі, як і мазі, повинні володіти певними консистентними властивостями, які характеризуються реологічними показниками: пластичністю, в'язкістю, періодом релаксації, від яких значною мірою залежить рівномірність розподілу даної лікарської форми на поверхні шкіри, ступінь вивільнення активної речовини з основи та їі проникнення в осередок ураження.

Реологічні показники (пластичність, еластичність, структурна в'язкість, тиксотропність тощо) є найважливішою характеристикою, що визначає стійкість структурованих систем і $є$ об'єктивним контролем їх якості при виробництві та зберіганні. Найбільш важливою реологічною характеристикою, що визначає властивості дисперсної системи, 
$\epsilon$ в'язкість (внутрішнє тертя). Вивчення структурної в'язкості гелю 3 екстрактом хмелю вуглекислотного $1 \%$ проводили методом ротаційної віскозиметрії. Для визначення структурної в'язкості зразку гелю використовували циліндр S2 віскозиметру «Реотест-2». Дослідження проводили при температурі $22^{\circ} \mathrm{C}$. За даними вимірювання визначали напругу зсуву та структурну в'язкость зразку гелю. Результати вивчення структурної в'язкості гелю з екстрактом хмелю вуглекислотного $1 \%$ наведені в таблиці 1 .

В результаті проведеного експерименту було визначено напругу зсуву i структурну в'язкість розробленого гелю, що сягали 38,74-193,05 Па і 38,74-0,44 Па • с, відповідно, при градієнту швидкості зсуву в інтервалі від 1,0 $\mathrm{c}^{-1}$ до 437,4 $\mathrm{c}^{-1}$. Значення межі текучості 38,74 Па, що одержано в ході експерименту, характеризує видавлювання гелю з туби і дає можливість гарантувати оптимальні споживчі властивості лікарського засобу. Визначена консистенція гелю за показниками структурної в'язкості забезпечує зручність іiі застосування при нанесенні на поверхню шкіри, а також служать критерієм оцінки якості гелю як під час виготовлення, так і в процесі зберігання.

Таблиця 1

\section{Структурна в'язкість гелю на основі екстракту}

хмелю вуглекислотного

\begin{tabular}{|c|c|c|c|c|}
\hline \multirow{2}{*}{$\begin{array}{c}\text { Градієнт } \\
\text { швидкості } \\
\text { зсуву (Dr), } \mathrm{c}^{-1}\end{array}$} & \multicolumn{4}{|c|}{$\begin{array}{c}\text { Значення напруги зсуву }(\tau), \\
\text { Па і структурної в'язкості }(\eta), \text { Па ·c }\end{array}$} \\
\hline & $\tau \downarrow$ & $\eta \downarrow$ & $\tau \uparrow$ & $\eta \uparrow$ \\
\hline 1,0 & $38,74 \pm 1,30$ & $38,74 \pm 1,30$ & $26,82 \pm 1,30$ & $26,82 \pm 1,30$ \\
\hline 1,8 & $44,10 \pm 1,35$ & $24,50 \pm 0,75$ & $29,80 \pm 1,30$ & $16,56 \pm 0,72$ \\
\hline 3,0 & $48,87 \pm 1,43$ & $16,29 \pm 0,48$ & $33,38 \pm 1,60$ & $11,13 \pm 0,54$ \\
\hline 5,4 & $53,61 \pm 1,70$ & $9,93 \pm 0,32$ & $35,16 \pm 1,60$ & $6,51 \pm 0,30$ \\
\hline 9,0 & $58,50 \pm 1,80$ & $6,50 \pm 0,20$ & $37,55 \pm 1,80$ & $4,17 \pm 0,20$ \\
\hline 16,2 & $78,98 \pm 1,60$ & $4,88 \pm 0,09$ & $44,10 \pm 1,70$ & $2,72 \pm 0,10$ \\
\hline 27,0 & $93,60 \pm 1,75$ & $3,46 \pm 0,07$ & $53,04 \pm 1,75$ & $1,96 \pm 0,07$ \\
\hline 48,6 & $111,15 \pm 1,85$ & $2,29 \pm 0,04$ & $58,41 \pm 1,82$ & $1,20 \pm 0,04$ \\
\hline 81,0 & $134,55 \pm 1,65$ & $1,66 \pm 0,02$ & $64,35 \pm 1,85$ & $0,79 \pm 0,02$ \\
\hline 145,8 & $157,95 \pm 1,90$ & $1,08 \pm 0,01$ & $87,75 \pm 1,75$ & $0,60 \pm 0,01$ \\
\hline 243,0 & $175,50 \pm 1,90$ & $0,72 \pm 0,01$ & $117,00 \pm 2,00$ & $0,48 \pm 0,01$ \\
\hline 437,4 & $193,05 \pm 1,85$ & $0,44 \pm 0,01$ & $193,05 \pm 2,00$ & $0,44 \pm 0,01$ \\
\hline
\end{tabular}

${ }^{1} \mathrm{n}=5, \mathrm{P}<0,5$. 
Гелева лікарська форма, що застосована при розробці нового лікарського засобу з екстрактом хмелю вуглекислотного 1\% для лікування acne vulgaris, $є$ гідрофільною та має у своєму складі як високомолекулярні полімери (карбомер, ПЕО 400) так і багатоатомний спирт - пропіленгліколь, які здатні абсорбувати воду, і володіє вираженими осмотичними властивостями. Осмотичний ефект гідрофільних основ, що виготовлені з використанням вищезазначених речовин, продовжується до 18 годин і більше, таким чином, забезпечує пролонгацію дії лікарського засобу, однак може призвести до зневоднення здорової клітини, зниження іiі біологічної активності та пошкодження. Дослідження осмотичних властивостей зразка оптимального складу, початкова маса якого складала 3,0 г, показало, що протягом проведення експерименту дослідний зразок абсорбує воду поступово - через 1 год. маса води, яка поглинена, складає 0,78 г (26\%), через 2 год. - 1,02 г (34\%), через 3 год. - 1,17 г (39\%). Подальше вивчення осмотичної активності зразка показало, що дослідний зразок абсорбує воду протягом 9 год., а на 10-11 год. - припиняє поглинати воду і досягає рівноваги. Деталі представлені у таблиці 2.

Таблиця 2

Осмотична активність гелю на основі екстракту хмелю вуглекислотного $1 \%{ }^{1}$

\begin{tabular}{|c|c|c|}
\hline \multirow{2}{*}{$\begin{array}{c}\text { Час поглинання, } \\
\text { год }\end{array}$} & \multicolumn{2}{|c|}{$\begin{array}{c}\text { Осмотична активність зразка гелю } \\
\text { з екстрактом хмелюо вуглекислотного 1\% }\end{array}$} \\
\cline { 2 - 3 } & Абсорбована вода, г & Абсорбована вода, \% \\
\hline 1,0 & $0,78 \pm 0,05$ & $26,00 \pm 1,70$ \\
\hline 2,0 & $1,02 \pm 0,06$ & $34,00 \pm 2,00$ \\
\hline 3,0 & $1,17 \pm 0,06$ & $39,00 \pm 2,00$ \\
\hline 4,0 & $1,29 \pm 0,05$ & $43,00 \pm 1,70$ \\
\hline 5,0 & $1,50 \pm 0,08$ & $50,00 \pm 2,70$ \\
\hline 6,0 & $1,68 \pm 0,08$ & $56,00 \pm 2,70$ \\
\hline 7,0 & $1,83 \pm 0,07$ & $61,00 \pm 1,70$ \\
\hline 8,0 & $2,04 \pm 0,05$ & $68,00 \pm 1,70$ \\
\hline 9,0 & $2,22 \pm 0,06$ & $74,00 \pm 2,00$ \\
\hline 10,0 & $2,46 \pm 0,07$ & $82,00 \pm 2,30$ \\
\hline 11,0 & $2,46 \pm 0,07$ & $82,00 \pm 2,30$ \\
\hline
\end{tabular}

${ }^{1}$ Показники представлені у вигляді значень п’ятикратних досліджень. 
Визначена помірна осмотична активність розробленого складу лікарського засобу з екстрактом хмелю вуглекислотного $1 \%$ у формі гелю, яка сягає 82\%, забезпечить пролонгацію дії гелю та не дасть можливості зневоднити клітину шкіри і призвести до іiї некрозу, що має важливе значення при лікуванні acne vulgaris.

Аналізуючи осмотичну активність зразка обраного складу можна відзначити, що розроблений лікарський засіб з екстрактом хмелю вуглекислотного $1 \%$ у формі гелю проявляє помірну осмотичну активність і адсорбує незначну кількість води - близько $82 \%$, що має важливе значення при лікуванні acne vulgaris. На відміну від референтного препарату (мазь «Ілон»), який не проявляє осмотичних властивостей через ліофільність основи, розроблений гель має переваги за вибраною гідрофільною основою, крім пролонгації дії, - за ступенем і кінетикою вивільнення активної речовини з основи та подалі іiі проникнення в осередок ураження.

Крім вищезазначених фізичних i фізико-хімічних показників м'яких лікарських засобів - однорідності, осмотичної активності і реологічних властивостей, не менш важливою характеристикою якості гелю є його термостабільність. За результатами проведеного експерименту встановлено, що зразки розробленого гелю при їх витримуванні по черзі при температурі $4,0^{\circ} \mathrm{C}, 42,0^{\circ} \mathrm{C}$ і кімнатній температурі протягом визначеного за методикою часу не розшаровуються, мають міцну структуру та не руйнуються. Результати дослідження впливу температури на стійкість розробленого гелю доводять його фізико-хімічну стабільність.

\section{3. Чутливість найбільш клінічно значущих різновидів збудників acne vulgaris до дії гелевої композиції з екстрактом хмелю вуглекислотного}

На шкірі, схильній до враження акне, вирізняють чисельні групи мікроорганізмів, такі як P. acnes, Staphylococcus epidermidis, S. aureus, S. saprophyticus, стрептококи, ліпофільні дріжджі роду Malassezia, раніше відомі як Pityrosporum (P. ovale та P. orbiculare). Стафілококи, пропіонобактерії та гриби роду Malassezia є мікроорганізмами, що складають до 99\% мікрофлори здорової шкіри [2, р. 425-433; 6, p. 61-81].

Вивчення шкіри хворих на акне виявило домінування стафілококів у двох третин $(79,6 \%)$ пацієнтів з превалюванням штамів $S$. aureus 
(48,9\%) за умов вказаної патології. Останньому великою мірою сприяють екскоріації шкіри в області висипань та висока частота виявлення S. aureus.

У більш глибоких шарах фолікулів виявляються мікроанаеробні пропіонобактерії: P. acnes (тип 1), P. granulosum (тип 2) та $P$. parvum (тип 3). Більшість науковців вважає $P$. acnes основним видом бактерій, які зумовлюють розвиток вугрової хвороби, оскільки вони не мають виражених вірулентних властивостей та не проникають у шкіру, а зосереджуються у вивідних протоках сальних залоз [11, p. 173-180].

Окремими авторами визначено наявність $S$. aureus (57-83\%), біохімічно неактивні грампозитивні палички і мікрококи (P. granulosum, $S$. aureus та $S$. viridas). Симбіоз анаеробного $P$. acnes i аеробного $S$. aureus вважають однією з безпосередніх причин розвитку вугрової хвороби. Бактеріологічними дослідженнями за умов розвитку акне виявлено, що асоціації мікробів зустрічаються в 1,7 рази частіше за монокультури: $17 \%$ становлять монокультури $S$. aureus, $20 \%$ - S. piogenes, $33 \%$ - асоціація S. epidermidis з S. enaerobius, $18 \%$ S. epidermidis 3 S. viridas, $12 \%$ - грампозитивні $S$. saprophyticus і грамнегативні Escherichia coli.

У комедонах, крім P. acnes і стафілококів, виділяють дріжджоподібні гриби (Malassezia), які також мають патогенетичне значення. Вважають, що P. ovale та P. acnes, які у здорових осіб поводяться як сапрофіти, в умовах ослаблення захисних властивостей шкіри цілком спроможні викликати ії ураження. Етіопатогенез акне має поліморфну палітру, де не останню роль відіграють гриби роду Candida.

Надалі проводили поглиблене мікробіологічне дослідження оптимального гелю з ЕХВ по відношенню до найбільш значущих збудників acne vulgaris.

Визначення протимікробної активності вибраного зразку гелю 3 ЕХВ проводили за методом дифузії в агар у модифікації «колодязів». Для дослідження було обрано найбільш розповсюджені збудники асnе vulgaris 3 різних таксономічних груп. Мікробне навантаження для проведення мікробіологічного дослідження становило 0,5 одиниць за стандартом McFarland.

Специфіка досліджених мікроорганізмів з огляду на їхню протимікробну та протигрибкову активність відображена в таблиці 3. 
Таблиця 3

Протимікробна та протигрибкова активність зразку гелю 3

ЕХВ до найбільш розповсюджених збудників acne vulgaris

\begin{tabular}{|c|l|c|c|}
\hline $\begin{array}{c}\text { № } \\
\text { 3/п }\end{array}$ & \multicolumn{1}{|c|}{ Тест-штамів мікроорганізмів } & Гель № 8 & $\begin{array}{c}\text { Контроль } \\
\text { «Ілон» }\end{array}$ \\
\hline $\mathbf{1}$ & \multicolumn{1}{|c|}{$\mathbf{2}$} & $\mathbf{3}$ & $\mathbf{4}$ \\
\hline 1 & Staphylococcus aureus № 16586 & $26,2 \pm 0,3$ & $22,3 \pm 0,5$ \\
\hline 2 & Staphylococcus aureus № 16588 & $25,4 \pm 0,4$ & $21,8 \pm 0,3$ \\
\hline 3 & Staphylococcus aureus № 16590 & $26,0 \pm 0,2$ & $21,4 \pm 0,3$ \\
\hline 4 & Staphylococcus epidermidis № 16593 & $26,1 \pm 0,3$ & $22,4 \pm 0,2$ \\
\hline 5 & Staphylococcus epidermidis № 16589 & $26,5 \pm 0,5$ & $21,4 \pm 0,2$ \\
\hline 6 & Staphylococcus haemolyticus № 16595 & $26,4 \pm 0,7$ & $22,4 \pm 0,5$ \\
\hline 7 & Propionibacterium acnes & $22,5 \pm 0,8$ & $21,3 \pm 0,7$ \\
\hline 8 & Candida albicans (Cкляp-31) & $22,4 \pm 0,6$ & $20,4 \pm 0,3$ \\
\hline 9 & Candida albicans (Скляp-20) & $21,8 \pm 0,7$ & $21,4 \pm 0,7$ \\
\hline 10 & Candida rugosa (Скляp-2/1) & $23,1 \pm 0,7$ & $21,2 \pm 0,2$ \\
\hline 11 & Candida famata 40 б/3 & $22,6 \pm 0,2$ & $20,1 \pm 0,2$ \\
\hline 12 & Candida catenulate (Скляp-27) & $22,5 \pm 0,8$ & $20,2 \pm 0,3$ \\
\hline 13 & Malassezia furfur & $21,3 \pm 0,5$ & $20,3 \pm 0,2$ \\
\hline 14 & Malassezia sympodialis & $21,3 \pm 0,4$ & $20,5 \pm 0,3$ \\
\hline 15 & Malassezia globosa & $22,1 \pm 0,8$ & $20,1 \pm 0,4$ \\
\hline 16 & Malassezia slooffiae & $21,5 \pm 0,4$ & $20,1 \pm 0,8$ \\
\hline 17 & Malassezia pachydermatis & & $20,5 \pm 0,6$ \\
\hline
\end{tabular}

При дослідженні антистафілококкової дії оптимального зразку гелю з ЕХВ щодо тест-штаммів мікроорганізмів роду Staphylococcus spp. виявлено, що усі піддослідні штами мікроорганізмів виявили високу чутливість до зразку гелю з ЕХВ, зони затримки росту коливалась у межах 25,4 $\pm 0,4-26,5 \pm 0,5$ мм, що значно перевищувало показники препарату порівняння, зони затримки росту якого склали $21,4 \pm 0,2-22,4 \pm 0,5$ мм.

При вивченні протимікробної дії обраного зразку гелю з ЕХВ щодо тест-штаму Propionibacterium acnes визначено, що даний тест-штам виявився чутливим до дії піддослідного зразку гелю, зона затримки росту дорівнювала $22,5 \pm 0,8$ мм, що було вище ніж у препарату контролю, зона затримки росту якого склала $21,3 \pm 0,7$ мм.

При дослідженні протигрибкової активності оптимального зразку гелю з ЕХВ щодо тест-штамів грибів роду Candida spp. та Malassezia 
spp. встановлено, що зони затримки росту усіх піддослідних тест-штамів знаходились у межах 21,3 $\pm 0,4-23,1 \pm 0,7$ мм, що було вище ніж у контролі (зона затримки росту 20,1 $\pm 0,8-21,4 \pm 0,7$ мм).

Таким чином, за результатами вивчення протимікробної та протигрибкової активності нового лікарського гелю з ЕХВ у відношенні до найбільш значущих збудників acne vulgaris, встановлено, що рівень антибактерійної та протигрибкової дії оптимального складу гелю 3 EXB вище, ніж з існуючим антисептичним препаратом - мазі «Ілон», яка використовується у дерматології для лікування акне.

\section{4. Висновки}

Аналізуючи осмотичну активність зразка обраного складу можна відзначити, що розроблений лікарський засіб з екстрактом хмелю вуглекислотного 1\% у формі гелю проявляє помірну осмотичну активність і адсорбує незначну кількість води - близько $82 \%$, що має важливе значення при лікуванні acne vulgaris. На відміну від референтного препарату (мазь «Ілон»), який не проявляє осмотичних властивостей через ліофільність основи, розроблений гель має переваги за вибраною гідрофільною основою, крім пролонгації дії, - за ступенем і кінетикою вивільнення активної речовини з основи та подалі їі проникнення в осередок ураження.

Крім вищезазначених фізичних i фізико-хімічних показників м'яких лікарських засобів - однорідності, осмотичної активності і реологічних властивостей, не менш важливою характеристикою якості гелю $є$ його термостабільність. За результатами проведеного експерименту встановлено, що зразки розробленого гелю при їх витримуванні по черзі при температурі $4,0^{\circ} \mathrm{C}, 42,0^{\circ} \mathrm{C}$ і кімнатній температурі протягом визначеного за методикою часу не розшаровуються, мають міцну структуру та не руйнуються. Результати дослідження впливу температури на стійкість розробленого гелю доводять його фізико-хімічну стабільність.

Таким чином, за результатами вивчення протимікробної та протигрибкової активності нового лікарського гелю з ЕХВ у відношенні до найбільш значущих збудників acne vulgaris, встановлено, що рівень антибактерійної та протигрибкової дії оптимального складу гелю 3 EXB вище, ніж з існуючим антисептичним препаратом - мазі «Ілон», яка використовується у дерматології для лікування акне. 


\section{References:}

1. Basak S.A., Zaenglein A.L. (2013). Acne and its management. Pediatrical Review, 34(11), 479-497.

2. Hori K., Matsumoto S. (2010). Bacterial adhesion: from mechanism to control. Biochemical Engineering Journal, 48(3), 424-434.

3. Kapczynski D., Meinersmann R., Lee M. (2000). Adherence of Lactobacillus to intestinal cells in culture correlates with fi bronectin binding. Current microbiology. № 41. P. 136-141.

4. Paulson D.S. (2008). Biostatistics and microbiology: a survival manual. Springer Science \& Business Media. 100 p.

5. Sadava E.E., Krpata D.M., Gao Y., Novitsky Y.W., Rosen M.J. (2013). Does presoaking synthetic mesh in antibiotic solution reduce mesh infections? An experimental study. Journal of Gastrointestinal Surgery, 17(3), 562-568.

6. Egert M. (2016). The microbiota of the human skin. Edv. Exp. Med. Bio l, Vol. 902, P. 61-81.

7. Kaprel'yants L., Krupitskaya L. (2017). Probiotic properties and biotechnological potential of propionic acid bacteria. Microbiology and biotechnology, No. 1, p. 6-15.

8. Negin Naghdi, Masood Ghane (2017). A comparison of culture and PCR methods for identifying Propionibacterium acnes in lesions isolated from patients with acne. Turkish Journal of Medical Sciences, № 47, p. 967-972.

9. Zaenglein A.L., Pathy A.L., Schlosser B.J. (2016). Guidelines of care for the management of acne vulgaris. J Am Acad Dermatol, № 74(5), p. 945-973.

10. Fiedler F., Stangl G.I. (2017). Acne and nutrition: a systematic review. Acta Derm. Venereol, vol. 97, p. 7-9.

11. Swarup I., Gruskay J., Price M. (2018). Propionibacterium acnes infections in patients with idiopathic scoliosis: a case-control study and review of the literature. J. Child Orthop, vol. 12, p. 173-180.

12. Bhate K., Williams H.C. (2013). Epidemiology of acne vulgaris. Br. J. Dermatol, vol. 168, Is. 3, p. 474-485.

13. Barnes L.E., Levender M.M., Fleischer A.B. (2012). Quality of life measures for acne patients. Dermatol Clin, v. 30, p. 293-300.

14. William Danby F. (2018). Acne Causes and practical management. M.: «Geotar-Media», $446 \mathrm{p}$.

15. Bychkova N.Yu. (2014). Acne in general medical practice. Experimental and clinical dermatocosmetology, № 2, p. 39-41. 